\title{
Simulation of the dynamics of protozoa in the rumen
}

\author{
BY JAN DIJKSTRA* \\ Wageningen Agricultural University, Department of Animal Nutrition, Haagsteeg 4, \\ 6708 PM Wageningen, The Netherlands
}

(Received 4 May 1993 - Revised 17 January 1994 - Accepted 15 February 1994)

\begin{abstract}
A modified mathematical model is described that simulates the dynamics of rumen micro-organisms, with specific emphasis on the rumen protozoa. The model is driven by continuous inputs of nutrients and consists of nineteen state variables, which represent the $\mathbf{N}$, carbohydrate, fatty acid and microbial pools in the rumen. Several protozoal characteristics were represented in the model, including preference for utilization of starch and sugars compared with fibre, and of insoluble compared with soluble protein; engulfment and storage of starch; no utilization of $\mathrm{NH}_{3}$ to synthesize amino acids; engulfment and digestion of bacteria and protozoa; selective retention within the rumen; death and lysis related to nutrient availability. Comparisons between model predictions and experimental observations showed reasonable agreement for protozoal biomass in the rumen, but protozoal turnover time was not predicted well. Sensitivity analyses highlighted the need for more reliable estimates of bacterial engulfment rate, protozoal maintenance requirement, and death rate. Simulated protozoal biomass was increased rapidly in response to increases in dietary starch content, but further increases in starch content of a highconcentrate diet caused protozoal mass to decline. Increasing the sugar content of a concentrate diet, decreased protozoa, while moderate elevations of the sugar content on a roughage diet increased protozoal biomass. Simulated protozoal biomass did not change in response to variations in dietary neutral-detergent fibre (NDF) content. Reductions in dietary $\mathbf{N}$ resulted in an increased protozoal biomass. Depending on the basal intake level and dietary composition, protozoal concentration in the rumen was either increased or decreased by changes in feed intake level. Such changes in relative amounts of protozoal and bacterial biomass markedly affected the supply of nutrients available for absorption. The integration of protozoal, bacterial and dietary characteristics through mathematical representation provided an improved understanding of mechanisms of protozoal responses to changes in dietary inputs.
\end{abstract}

Ruminants: Computer simulation: Protozoa: Mathematical model

In ruminants the quantity and quality of nutrients absorbed from the digestive tract are generally quite different from those ingested because of the activity of the rumen microbial population. The significance of the rumen micro-organisms in the rumen digestion processes and consequently in animal production has been elaborated by many research workers (see Hungate, 1966). The role of rumen protozoa in these processes has been the subject of much debate and our knowledge of rumen protozoa and their function is poor compared with that of rumen bacteria. The contribution of protozoa to total rumen microbial biomass may equal that of bacteria (Hungate, 1966), suggesting possibly an important role of protozoa in ruminal fermentation processes. Yet, in numerous experiments, their presence has been demonstrated to be non-essential for the ruminant (e.g. Veira, 1986). Studies on the effects of elimination of protozoa from the rumen have been performed to increase knowledge of the overall effect of protozoa in rumen

* Present address: AFRC Institute of Grassland and Environmental Research, North Wyke Research Station, Okehampton, Devon EX20 2SB. 
fermentation, but the modifications brought about as a result of defaunation are not systematic. Since bacterial and protozoal metabolism differ in many aspects, establishment of the role of protozoa in rumen digestion processes and of the effects of defaunation on these processes should include the complex relationships between protozoa, bacteria, animal and dietary factors (Jouany $e$ t al. 1988). At present, such an integrative approach, with the aim to increase understanding of interactions between several components of a biological system, is possible only through mathematical representation of the processes involved as a series of nonlinear differential equations (Thornley \& Johnson, 1990). The explicit representation of protozoal metabolism within mathematical models of rumen fermentation has received only limited attention (Dijkstra et al. 1990).

The present paper describes some modifications of a mathematical model which simulates the dynamics of ingested nutrients and of microbes within the rumen of cattle, with specific emphasis on the role of the rumen protozoa. The model is a development of the rumen model of Dijkstra $e t$ al. (1992), such that in addition to bacteria the protozoa have been included as a state variable. This explicit representation allows evaluation of the interactions of protozoa with bacteria and dietary characteristics. The principal objective of the model is to evaluate concepts and data in order to provide a quantitative understanding of the protozoal dynamics and of the integration of protozoal functioning with other micro-organisms and diet composition.

\section{THE MODEL}

Principal fluxes for grouped nutrients in the model are shown in Fig. 1. The abbreviations used to define the entities in the model are listed in Table 1 . The model is modified from the dynamic, deterministic rumen model described by Dijkstra et al. (1992). The original model comprised seventeen state variables and several hundred equations. Hence, only a brief summary of the additions to the original model and parameterization of new variables will be given. A full mathematical statement of the modified model can be found elsewhere (Dijkstra, 1993, chapter 4). Neal et al. (1992) evaluated the original model and concluded from sensitivity and validation results that microbial recycling through the activities of the rumen protozoa had to be represented more accurately. In that model, protozoa are represented as a fixed part of the amylolytic microbial pool, consisting of both bacteria and protozoa, and many rate constants in equations describing protozoal activities are assigned the same values as for bacteria. In view of the objective of the present model, a lower degree of aggregation is appropriate (Gill et al. 1989). Thus, bacteria and protozoa were represented in separate pools and the parameters in equations related to protozoal metabolic activity were assigned values derived from relevant literature, where available. General protozoal characteristics, which differ from bacterial characteristics and have been represented in the present model, are: utilization of starch and soluble sugars as well as fibre as major sources of $\mathrm{C}$, with preference for the former; engulfment of starch to form storage polysaccharides; no utilization of $\mathrm{NH}_{3}$ to synthesize amino acids de novo; direct incorporation of dietary or microbial fatty acids to meet lipid formation requirements; preference for insoluble to soluble protein as $\mathrm{N}$ source; engulfment and digestion of bacteria and protozoa; relatively low maximum growth rates; selective retention within the rumen; death and subsequent lysis related to nutrient availability. Justification for the various assumptions associated with this representation of protozoal characteristics is presented in the relevant sections below. The flux equations are generally described by Michaelis-Menten forms. Although based on enzyme kinetics, such expressions are applicable to the kinetics of microbe and cell cultivation (Pirt, 1975) and to studies of transport of molecules and ions across cell membranes (Stein, 1986). Moreover, these 

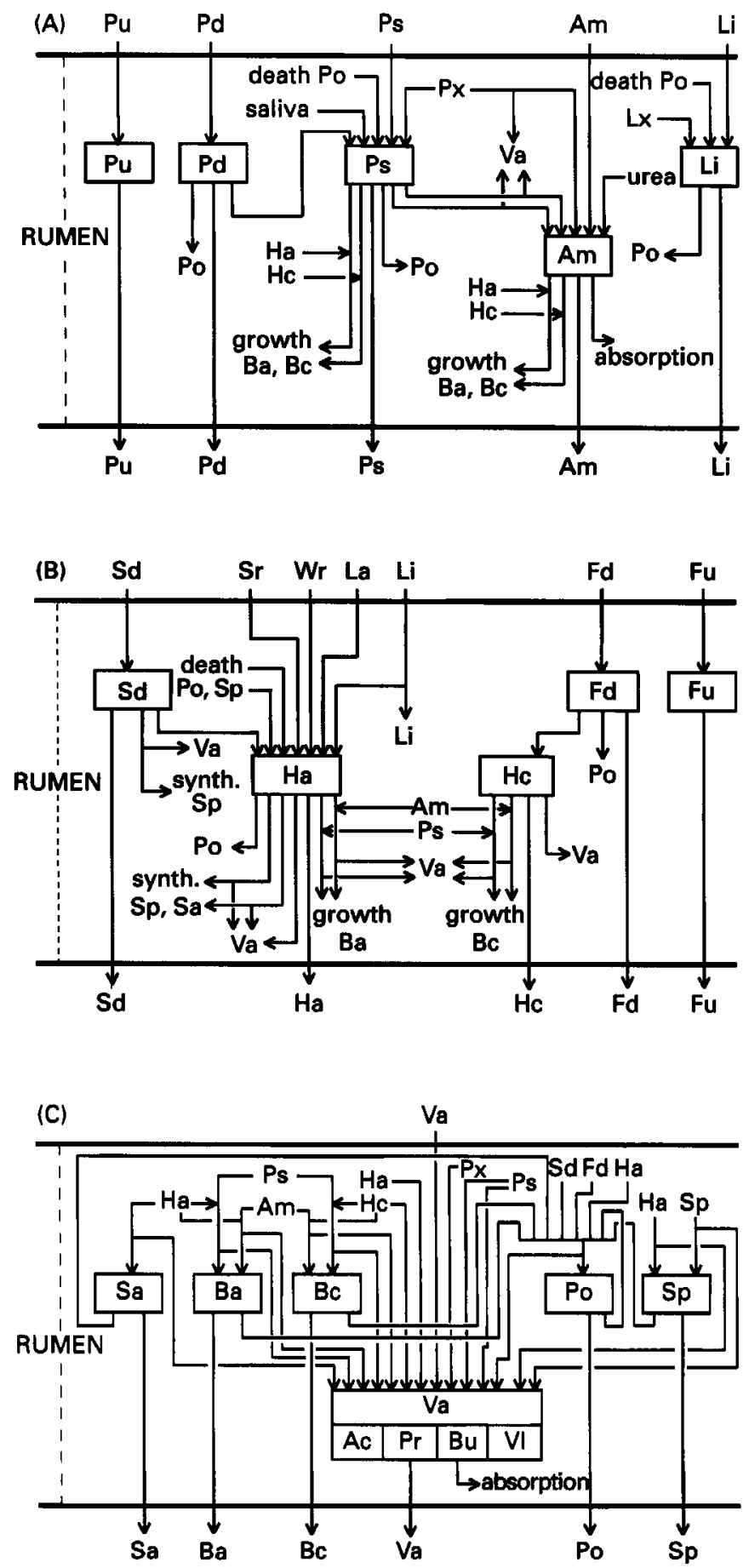

Fig. 1. Diagrammatic representation of a rumen model with respect to input and output of protein, ammonia and lipid (panel A), fibre, starch and hexose (panel B), and microbial matter and volatile fatty acids (panel C). Boxes enclosed by solid lines indicate state variables and arrows indicate fluxes. For definitions of abbreviations, see Table 1. 
Table 1. Symbols for entities and processes used in the model

\begin{tabular}{|c|c|c|c|}
\hline Symbol & Entity & Symbol & Entity \\
\hline $\mathbf{A b}$ & Absorption from rumen & Pd & Rumen degradable protein \\
\hline Ac & Acetic acid & $\mathbf{P m}$ & Protozoal maintenance \\
\hline $\mathrm{Am}$ & Ammonia & Po & Protozoa \\
\hline $\mathrm{Ba}$ & Amylolytic bacteria & Pr & Propionic acid \\
\hline Bc & Cellulolytic bacteria & Ps & Rumen fluid soluble protein \\
\hline Bx & Bacteria, general & $\mathbf{P u}$ & Rumen undegradable protein \\
\hline $\mathrm{Bu}$ & Butyric acid & $\mathbf{P x}$ & Engulfed protein \\
\hline $\mathrm{Ce}$ & Cellulose & $\mathbf{R u}$ & Rumen \\
\hline De & Death of protozoa & $\mathbf{S a}$ & Amylolytic bacterial storage \\
\hline Ex & Exit from rumen into lower tract & & polysaccharides \\
\hline $\mathbf{F d}$ & Rumen degradable neutral-detergent fibre & $\mathrm{Sd}$ & Rumen degradable starch \\
\hline $\mathrm{Fe}$ & Feed & Sf & Proportion of engulfed starch \\
\hline Fl & Rumen fluids & & fermented for energy \\
\hline $\mathrm{Fu}$ & Rumen undegradable neutral-detergent fibre & Sl & Saliva \\
\hline $\mathrm{Ha}$ & Amylolytic hexose & So & Rumen solids \\
\hline Hc & Cellulolytic hexose & Sp & Protozoal storage polysaccharides \\
\hline $\mathrm{He}$ & Hemicellulose & $\mathbf{S r}$ & Rumen fluid soluble starch \\
\hline Hf & Proportion of hexose fermented for energy & St & Starch \\
\hline In & Intake & $\mathrm{Ue}$ & Urea \\
\hline $\mathrm{La}$ & Lactic acid & Va & Volatile fatty acids \\
\hline Lc & Lactic acid carbohydrate equivalents & $\mathrm{Vl}$ & Valeric acid \\
\hline Le & Lactic acid energy equivalents & $\mathbf{W r}$ & Water soluble carbohydrates \\
\hline $\mathbf{L i}$ & Lipids & $\mathbf{X f}$ & Proportion of general engulfed \\
\hline $\mathbf{L x}$ & Engulfed lipids & & hexose fermented for energy \\
\hline $\mathbf{N i}$ & Nitrogen & $\mathbf{X x}$ & General engulfed hexose entity \\
\hline
\end{tabular}

equations have appealing properties for the partitioning of entities between fluxes in a mechanistic model (Gill et al. 1989).

\section{PARAMETERIZATION \\ Input parameters}

The input parameters to the model have not been changed from the original model (Dijkstra et al. 1992), with one exception. The definition of the fraction of protozoa in the microbial pools is no longer required, because in the modified version protozoa and bacteria have been represented separately.

\section{Rate constants}

Microbial pools, general. As described previously (Dijkstra et al. 1992), amylolytic bacteria $(\mathrm{Ba})$ and cellulolytic bacteria $(\mathrm{Bc})$ utilize hexose derived from non-structural carbohydrates and structural carbohydrates respectively. Protozoa (Po) are assumed to utilize both sources of carbon hexose (Coleman, 1986; Williams, 1989). On a range of diets, Czerkawski (1976) concluded that the composition of polysaccharide-free dry matter (DM) did not differ to a great extent between bacteria and protozoa. Hence, the polysaccharide-free microbial matter of all groups is assumed to be equal and has been given previously (Dijkstra et al. 1992). For simplicity, the predictable difference in cell wall content between bacteria and protozoa was ignored. The amounts of hexose, protein and $\mathrm{NH}_{3}$ required for biosynthesis of protozoal cells were calculated using the approach in the original model, and on the assumptions that, first, lipid requirements are met by direct incorporation of dietary and/or microbial long-chain fatty acids (Demeyer et al. 1978; Williams, 1986), and 
second, that the rate of protozoal amino acid formation from sources other than preformed amino acids is quantitatively unimportant (Coleman, 1986).

Degradable, insoluble protein pool $(P d)$. There is one modification to the input to this pool, which is the inclusion of uptake of Pd by protozoa. Other sources of protein taken up by protozoa are soluble protein and bacterial and protozoal protein. All protein taken up by protozoa (Px) can be incorporated into protozoal protein ( $\mathrm{Px}$ to $\mathrm{Po}$ ), fermented (Px to Am), or released into the rumen fluid again (Px to Ps) (Williams \& Coleman, 1988). As rationalized by Coleman (1986), protozoa will not utilize the engulfed protein for growth unless sufficient energy to support growth is available. Thus, a part of the engulfed protein is incorporated into protozoal protein, and the remainder is then partitioned between fermentation and release into rumen fluid, represented in a balance equation (see Dijkstra, 1993, chapter 4). It is assumed that all released protein is soluble. The maximum uptake rates of both insoluble and soluble protein by protozoa $(0.04 \mathrm{~mol} / \mathrm{g}$ Po per $\mathrm{d})$ are determined using the approach described in the original model (Dijkstra et al. 1992). The maximum utilization of protein for growth can be calculated from the requirement for protein per unit protozoal growth and the maximum growth rate $(4 \cdot 1 / \mathrm{d}$, described in the Sd pool section). In contrast with protozoal uptake of soluble material, which does not seem to be inhibited in the presence of storage polysaccharides $(\mathrm{Sp})$ within the protozoal cell (Coleman, 1967; Williams, 1989), protozoal uptake of insoluble material in the presence of $\mathrm{Sp}$ is assumed to be inhibited to the same extent as uptake of bacteria, explained in the Ba section. The rumen protozoa prefer insoluble compared with soluble protein, and show higher activity against the former (Forsberg et al. 1984; Wallace \& Cotta, 1988), whereas protozoal activity against insoluble protein is higher than bacterial activity (Nolan, 1989). Therefore, protozoal affinity constant for uptake of insoluble protein and soluble protein are set at respectively $1 / 6$ and twice the average bacterial affinity constant in the original model (Dijkstra et al. 1992). The maximum fermentation rate of protein by protozoa is assumed to be equal to that of bacteria since, on the one hand, extracts of protozoa are more active than extracts from bacteria in deaminating amino acids (Hino \& Russell, 1985), but on the other hand, intact protozoa are less active than bacteria in producing $\mathrm{NH}_{3}$ from a range of proteins (Hino \& Russell, 1987). The affinity constant of engulfed protein to form $\mathrm{NH}_{3}(0.02 \mathrm{~mol} / \mathrm{g} \mathrm{Po})$ is calculated at the reference diet in the original model (Dijkstra et al. 1992), to partition approximately $50 \%$ of the protein remaining after protozoal growth requirements have been met to $\mathrm{NH}_{3}$, and to release the other $50 \%$ into rumen fluid (Coleman, 1975).

Soluble protein pool $(P s)$. There are two modifications to this pool, namely an input representing release of engulfed protein by protozoa, and an output representing uptake of Ps by protozoa. In the previous section the parameterization of Ps uptake, utilization and release by protozoa has been described.

Undegradable protein pool $(\mathrm{Pu})$. The equations representing $\mathrm{Pu}$ production and utilization have not been changed from those reported in the original model (Dijkstra et al. 1992).

Ammonia pool (Am). One major change to the Am pool has been included, which is the production of Am from fermentation of engulfed protein by protozoa, with parameters described in the Pd pool section. Uptake of Am for growth has been represented for bacteria only, because most protozoa cannot use urea or $\mathrm{NH}_{3}$ to synthesize amino acids de novo (Coleman, 1986; Jouany et al. 1988).

Lipid pool $(\mathrm{Li})$. The modifications in the lipid pool are related to the uptake of $\mathrm{Li}$ by protozoa and the release of part of the engulfed microbial and dietary $\mathrm{Li}$ into rumen fluid. The maximum rate of $\mathrm{Li}$ uptake $(0.75 \mathrm{mmol} \mathrm{Li} / \mathrm{g}$ Po per $\mathrm{d})$ is calculated from the maximum rate of protozoal growth (see Sd pool section) and the chemical composition of 
protozoa. The affinity constant for $\mathrm{Li}$ uptake $(0.01 \mathrm{~mol} / \mathrm{l})$ is calculated to partition sufficient $\mathrm{Li}$ to meet protozoal growth requirements at low $\mathrm{Li}$ contents of the diet. The amount of engulfed $\mathrm{Li}$ released into rumen fluid is represented in a balance equation, assuming that all engulfed Li not utilized for growth is released again. It should be noted that high $\mathrm{Li}$ concentrations in the diet are toxic to protozoa and cause a reduction or elimination of protozoa in the rumen (Jouany et al. 1988). In the absence of quantitative data, this aspect has been ignored and it is assumed that the Li concentration in simulated diets is at a level too low to affect protozoa deleteriously.

Degradable starch pool $(S d)$. In this pool, modifications to the previous model (Dijkstra et al. 1992) are related to the uptake of $\mathrm{Sd}$ for protozoal growth and $\mathrm{Sp}$ formation. Maximum velocity of starch engulfment is calculated from uptake rates of carbohydrates to achieve maximum protozoal growth rate and $\mathrm{Sp}$ formation. Values of maximum growth rates reported in the literature for smaller protozoa, which primarily utilize starch and sugars but not fibre, and larger protozoa, which utilize fibre, starch and sugars, are $4 \cdot 1$ and 1.7 /d respectively (reviewed by Williams \& Coleman, 1988). Application of the Pirt (1965) double reciprocal equation of growth yield $v$. dilution rate and protozoal maintenance requirement (described in the Po pool section) yields a maximum uptake rate of starch or sugars and of fibre for maintenance and growth of 0.036 and $0.020 \mathrm{~mol} / \mathrm{g}$ Po per $\mathrm{d}$ respectively. On the assumption that the maximum content of $\mathrm{Sp}$ in protozoal DM is $40 \%$ (Czerkawski, 1976), maximum uptake rates of starch and sugars to form storage polysaccharides are $0.022 \mathrm{~mol} / \mathrm{g}$ Po per d. The protozoal affinity constants of Sd and $\mathrm{Ha}$ for maintenance and growth of protozoa and for Sp formation are assigned values based on a priority basis, given the following experimental observations. First, several protozoal species do not synthesize Sp from soluble sugars (for a review, see Coleman, 1986) and consequently, the affinity constant of $\mathrm{Ha}$ for protozoal maintenance and growth has been set at a lower value than the affinity constant of $\mathrm{Ha}$ for $\mathrm{Sp}$ formation. Second, rapid uptake and storage of starch within the protozoal cell can occur (Williams \& Coleman, 1988) and, consequently, the affinity constant of Sd for protozoal maintenance and growth has been set at a higher value than the affinity constant of $\mathrm{Sd}$ for $\mathrm{Sp}$ formation. The utilization of $\mathrm{Sd}$ and $\mathrm{Ha}$ for Sp synthesis is inhibited sigmoidally by the Sp content of the protozoal biomass, because starch is engulfed rapidly when protozoa have been starved for a certain period or when the starch content of protozoa is low, but starch uptake is reduced when protozoa are completely filled with starch particles (Coleman, 1986). Equally, on soluble sugar substrates, $\mathrm{Sp}$ content is not increased above a certain maximum level even if soluble sugar concentration in the fluid is increased further (Van Hoven \& Prins, 1977). Thus, above the maximum $\mathrm{Sp}$ level, synthesis of $\mathrm{Sp}$ from $\mathrm{Sd}$ and $\mathrm{Ha}$ is assumed to be completely inhibited and a sigmoidal response equation, giving a sharp switch-off characteristic is appropriate (Gill et al. 1989). The values of these parameters can be found elsewhere (Dijkstra, 1993, chapter 4).

Degradable fibre pool $(F d)$. The addition of the utilization of Fd by protozoa is the only modification to this pool. The maximum uptake rate of $\mathrm{Fd}$ by protozoa and the inhibition of Fd uptake related to the relative amounts of $\mathrm{Sp}$ is explained in the $\mathrm{Sd}$ and $\mathrm{Ba}$ sections. In the absence of quantitative data the affinity constant of Fd $(0.353 \mathrm{~mol} / \mathrm{l})$ has been set arbitrarily. In contrast to bacteria, Fd utilization by protozoa is assumed not to be inhibited directly by low $\mathrm{pH}$ values of rumen fluid. Rather, an indirect effect as a result of high availability of (rapidly degradable) substrates, resulting in high protozoal death rates (see Po pool section) and low pH values, has been included.

Undegradable fibre pool $(F u)$. The $\mathrm{Fu}$ pool is not modified from the original model (Dijkstra et al. 1992).

Amylolytic hexose pool $(\mathrm{Ha})$. The modifications to the inputs of this pool relate to 
hydrolysis of protozoal $\mathrm{Li}$ and $\mathrm{Sp}$, released upon death and lysis of protozoa, with parameters described in previous sections and in the Po pool section. The yield factors of hexose derived from $\mathrm{Li}$ are calculated on the assumption that $1 \mathrm{~mol} \mathrm{Li}$ yields $0.5 \mathrm{~mol}$ hexose (from the glycerol part of $\mathrm{Li}$ ). The modification to the outputs from the $\mathrm{Ha}$ pool is the uptake of $\mathrm{Ha}$ by protozoa for maintenance and growth and for $\mathrm{Sp}$ formation. Protozoal cells do not control soluble sugar uptake rate (Williams, 1979) and the Sp content of protozoal cells does not inhibit glucose uptake rate (Williams, 1989). Thus, the utilization of $\mathrm{Ha}$ by protozoa has been represented as an overall uptake rate, of which the amount utilized for Sp synthesis is subtracted while the remainder is utilized for maintenance and growth. This representation will rapidly increase death rate of protozoa at Ha concentration levels above the level supporting maximum $\mathrm{Sp}$ formation, thus simulating the observed lysis of holotrich protozoa in the presence of excess substrate (for a review, see Williams \& Coleman, 1988). Calculation of the rate constants involved has been described in the Sd pool section.

Cellulolytic hexose pool $(H c)$. The equations in the Hc pool have not been changed from those reported previously (Dijkstra et al. 1992).

Amylolytic bacterial pool $(B a)$. The major modification to the $\mathrm{Ba}$ pool is related to the engulfment of bacteria by protozoa. It is assumed that bacteria (amylolytic and cellulolytic) are engulfed in the proportion in which they are present. This assumption is based on experimental observations, which indicate that although selective engulfment of bacteria by some protozoal species might occur, no consistent pattern between protozoal species could be found (reviewed by Coleman, 1989). The maximum uptake rate of bacteria and the affinity constant of bacteria have been described in the original model (Dijkstra et al. 1992). In addition, the inhibitory effect of protozoal storage polysaccharides on engulfment of bacteria (Coleman, 1975) has been included. Observations made by Coleman (1975) with Entodinium caudatum indicate that this inhibition can be modelled in a sigmoidal way: first, in protozoa filled with relatively small amounts of starch, bacterial uptake rate is not limited; second, engulfment of bacteria is never completely inhibited, even if protozoa appear to be completely filled with starch. Based on these observations, a weak sigmoidal response and half-maximum rate achieved at assumed half-maximum amount of $\mathrm{Sp}$ are represented, and relevant parameter values have been given by Dijkstra (1993, chapter 4).

Amylolytic bacterial storage polysaccharides pool $(\mathrm{Sa})$. In addition to the original model (Dijkstra et al. 1992), engulfment of Sa has been represented, with parameters described in the previous section.

Cellulolytic bacterial pool $(B c)$. Like the Ba pool, the only change to the $\mathrm{Bc}$ pool is the representation of the inhibitory effect of $\mathrm{Sp}$ on bacterial engulfment. Parameter values are described in the Ba pool section.

Protozoal pool (Po). The Po pool is added to the original model (Dijkstra et al. 1992) to represent protozoal activities in the rumen. There is one input to this pool, from the utilization of carbohydrates taken up and not utilized for protozoal maintenance. In contrast to bacteria (see Dijkstra et al. 1992), the maintenance requirement of protozoa is assumed not to change with $\mathrm{N}$ availability, in view of the generally high availability of $\mathrm{N}$ sources for protein synthesis (Coleman, 1975). However, if the availability of engulfed protein to support protozoal growth is lower than the corresponding availability of energy, the production of protozoa is calculated according to the availability of the former, and the remaining carbohydrates are fermented completely. In the absence of data on maintenance requirements of protozoa, this value has been set at $8.5 \mathrm{mmol} / \mathrm{g}$ Po per d. Some justification for this value can be obtained from the figures on rate of endogenous amylopectin utilization by holotrich protozoa reported by Prins \& Van Hoven (1977) and Van Hoven $\&$ Prins (1977). On the assumption that the maximum amount of storage polysaccharides 
is $40 \%$ of total protozoal DM (Czerkawski, 1976) and that the endogenous fermentation represents the maintenance requirement of microbes, values between 7 and $10 \mathrm{mmol}$ hexose/g Po per d can be calculated. General hexose entities taken up are: degradable fibre and starch, amylolytic hexose, engulfed microbial polysaccharides, and hexose arising from the glycerol moiety of engulfed microbial lipid. The utilization rates of the hexose entities have been described in the relevant sections. There are three outputs from the pool; engulfment by other protozoa, death of protozoa and washout of protozoa from the rumen. Uptake of small protozoa by larger ones has been reported (reviewed by Coleman, 1986). However, in the absence of quantitative data, rate constants were assumed to be the same as for engulfment of bacteria. Protozoa have been observed to degenerate and burst, particularly on diets rich in easily degradable carbohydrates (for a review, see Williams \& Coleman, 1988). The cause of protozoal lysis is probably the inability of protozoa to control soluble substrate entry (Williams, 1979) and the subsequent intracellular build-up of acidic fermentation products (Prins \& Van Hoven, 1977). Thus, in the model, the amount of volatile fatty acids (VFA) produced from fermentation of hexose entities per unit of time and protozoal biomass will determine the death rate of protozoa. A sigmoidal response is assumed to obtain low death rates at low nutrient availabilities with a rapid increase when hexose entities taken up are increased. The value of maximum death rate is assumed to be the same as the maximum growth rate of protozoa (see Sd pool section), while the affinity and steepness parameters have been set arbitrarily (see Dijkstra, 1993, chapter 4). Protozoa are selectively retained within the rumen (for a review, see Jouany et al. 1988). Faichney (1989) summarized data on the outflow of protozoa and calculated that the fractional outflow rate of protozoa was only 0.45 of the fractional passage rate of solid material out of the rumen. This value has been adopted in the model.

Protozoal storage polysaccharides pool $(S p)$. This pool is added to the original model (Dijkstra et al. 1992) to accommodate variation in protozoal chemical composition (Dijkstra et al. 1990). There are two inputs to this pool, representing synthesis from $\mathrm{Ha}$ and $\mathrm{Sd}$, with utilization rates as explained in the relevant sections. The three outputs from this pool are equivalent to the outputs of the protozoal pool.

Volatile fatty acid pools (Ac, Pr, Bu and VI). These pools are modified to accommodate the production of VFA from fermentation of substrates by protozoa. The stoichiometric yield parameters for fermentation of individual substrates are given by Murphy et al. (1982). This set of yield parameters was used for bacteria as well as protozoa. Although it is recognized that rumen protozoa hardly produce propionic acid (for a review, see Williams \& Coleman, 1988), stoichiometric parameters as calculated by Murphy et al. (1982) do not account for differences in microbial populations in production of VFA. Besides, it is assumed that the type of VFA formed does not affect other rumen fermentation characteristics or the interactions between protozoa, bacteria and dietary factors and thus the differences in end-products produced by different microbial species on the same substrate have been ignored.

\section{Model summary}

The model is completely defined by the equations which have been described elsewhere (Dijkstra, 1993, chapter 4). The differential equations of the nineteen state variables are integrated numerically for given initial conditions and parameter values. The computer program was written in the simulation language ACSL (Advanced Continuous Simulation Language; Mitchell \& Gauthier, 1981) and run on a VAX computer. An integration interval of $\Delta t=0.01 \mathrm{~d}$ was used, with a fourth-order fixed-step-length Runga-Kutta method. The results presented in the next section were obtained by taking the predictions at $30 \mathrm{~d}$ to ensure steady state solutions. 
(A)

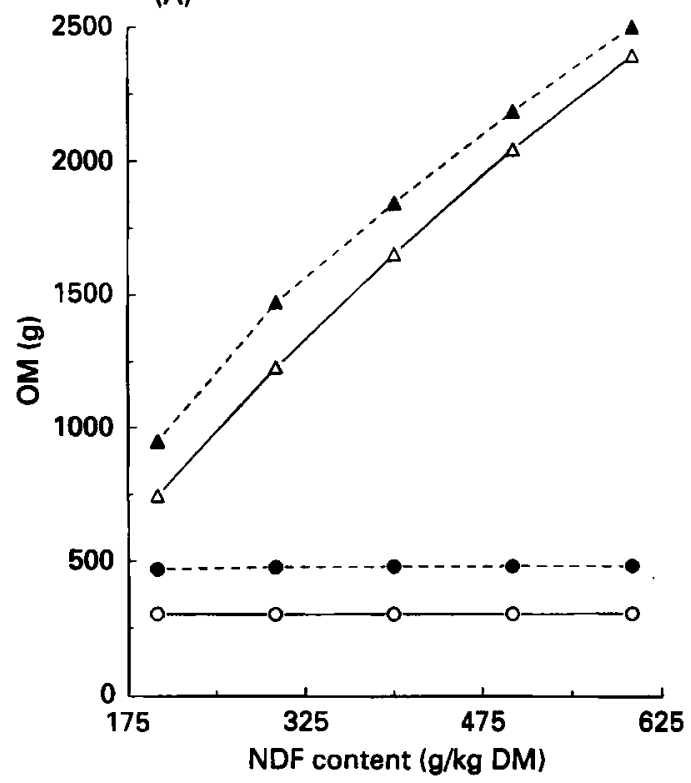

(C)

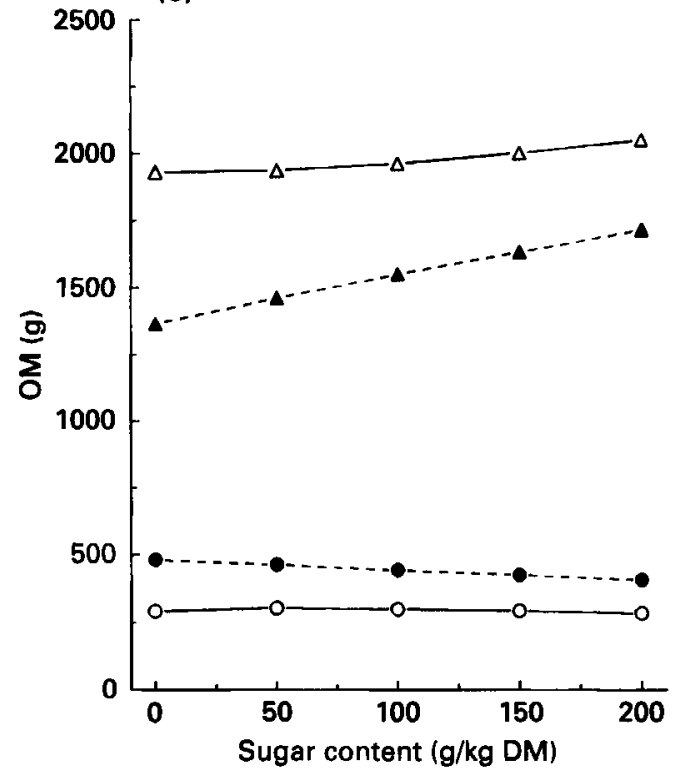

(B)

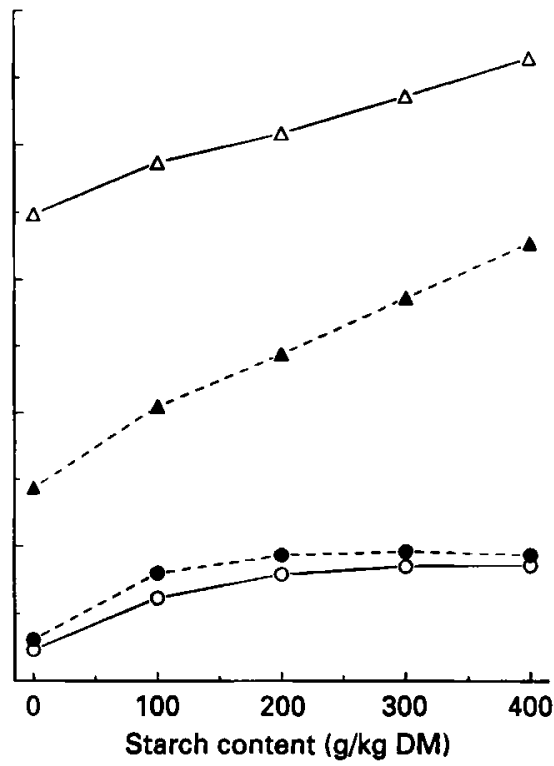

(D)

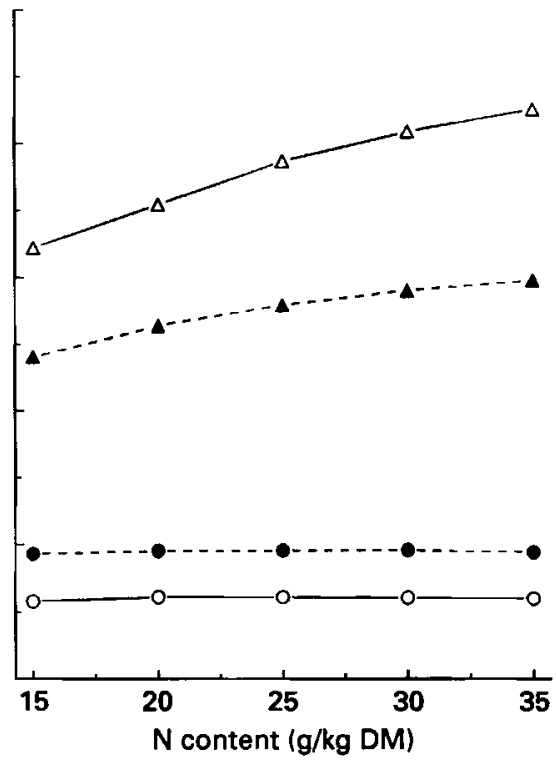

Fig. 2. The sensitivity of total microbial organic matter (OM) and of protozoal $O M$ in the rumen to the dietary content level of neutral-detergent fibre (NDF) (panel A), starch (panel B), sugars (panel C) and nitrogen (panel D) for the high-roughage diet (diet R) and the high-concentrate diet (diet $C$ ). ( $\triangle$ ), microbial OM for diet $R ;(\Delta)$, microbial OM for diet C; (O), protozoal OM for diet R; (O), protozoal OM for diet C. 


\section{RESULTS}

The results of model evaluation are presented in three parts. First, sensitivity of protozoal dynamics to changes in selected parameter values associated with protozoa was evaluated. Second, response of the model to changes in feed intake level and diet composition was examined. Finally, published experiments were simulated and the results of these simulations were compared with reported values.

\section{Sensitivity analysis}

In this section, only a brief summary of the results of the sensitivity analysis will be given. Full details of this analysis can be found elsewhere (Dijkstra, 1993, chapter 4). The sensitivity of the model to changes in selected parameters $( \pm 50 \%$ and $\pm 25 \%$ of model values) was examined on a high-roughage diet (diet R; $70 \%$ grass silage, $20 \%$ maize silage and $10 \%$ concentrates) and a high-concentrate diet (diet $\mathrm{C} ; 23 \%$ grass silage, $7 \%$ maize silage and $70 \%$ concentrates) at a simulated continuous feed intake of $18 \mathrm{~kg} \mathrm{DM} / \mathrm{d}$ for a dairy cow. Further details of the diets are given by Dijkstra (1993, chapter 4).

The sensitivity analyses indicated that the model is highly sensitive to bacterial engulfment rate, maintenance requirements of protozoa and death rate of protozoa. Decreasing the affinity parameter related to engulfment of bacteria greatly increased the simulated amount of bacterial matter engulfed. However, the simulated protozoal biomass was hardly affected because in the model it is assumed that significant amounts of engulfed microbial matter (in particular protein and nucleic acids) will be excreted in rumen fluid again (Coleman, 1975). As a result, the lower microbial biomass in the rumen decreased the simulated degradation of feed organic matter (OM) in the rumen. Changing the maintenance requirement of protozoa in the model had a very significant effect on the simulated protozoal and bacterial biomass, and hence on the simulated degradation and outflow of nutrients. Increasing the protozoal maintenance requirement to $150 \%$ of the model value or decreasing it to $75 \%$ of the model value resulted in simulated extinction of protozoa on both diets and extinction of cellulolytic bacteria on diet $\mathbf{C}$ respectively. The model appeared to be sensitive to changes in the death rate of protozoa as well. Increasing the affinity constant related to death of protozoa by $25 \%$ resulted in simulated disappearance of cellulolytic bacteria on diet $\mathrm{C}$, while a decrease of this affinity constant by $25 \%$ resulted in disappearance of protozoa on both diets. A full description of these changes has been given by Dijkstra (1993, chapter 4).

\section{Response to changes in input parameters}

The effects of varying the NDF, starch, sugars or $\mathrm{N}$ content of diets $\mathrm{R}$ and $\mathrm{C}$ on microbial $\mathrm{OM}$ in the rumen, while keeping all other parameters constant, are presented in Fig. 2. Increasing the dietary NDF content increased the total microbial $O M$ in the rumen, but did not or only to a minor extent increase ruminal protozoal OM (Fig. 2(A)). Changes in the amount of starch in the diet had a very pronounced effect on protozoal OM (Fig. 2(B)). On diet R, protozoal contribution to total microbial OM increased from $7 \%$ when no starch was included up to $17 \%$ at the $400 \mathrm{~g} / \mathrm{kg} \mathrm{DM}$ level. However, on diet $\mathrm{C}$ the protozoal biomass was seen to be slightly decreased at such high $(>300 \mathrm{~g} / \mathrm{kg} \mathrm{DM})$ starch contents. The reason for this reduction was the rapid increase in fractional protozoal death rate (from 0.74 on the lowest to $1.35 / \mathrm{d}$ on the highest starch level). Such elevated death rates were responsible for the decrease in protozoal biomass with increased dietary sugar levels on diet $C$ as well (Fig. 2(C)). However, on diet $R$ a maximum amount of protozoal $O M$ was reached at dietary sugar levels of approximately $75 \mathrm{~g} / \mathrm{kg} \mathrm{DM}$. Decreasing the $\mathrm{N}$ availability in the rumen by reducing the dietary $\mathrm{N}$ content decreased the microbial OM in the rumen 


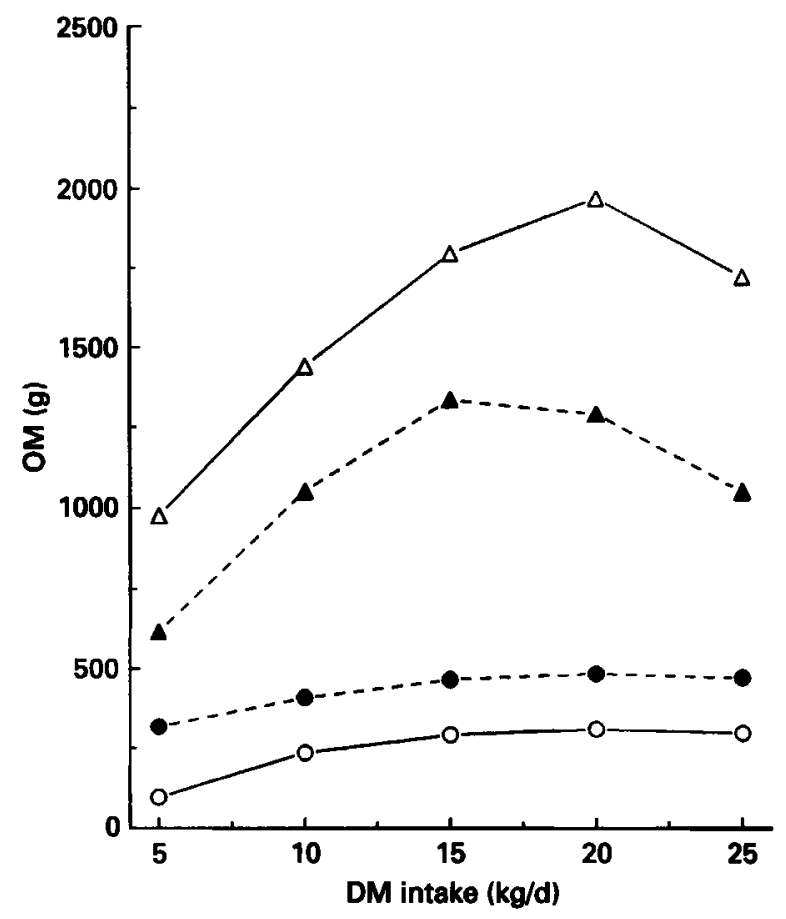

Fig. 3. The sensitivity of total microbial organic matter $(\mathrm{OM})$ and of protozoal $\mathrm{OM}$ in the rumen to the dry matter (DM) intake level for the high-roughage diet (diet R) and the high-concentrate diet (diet $C)$. ( $\triangle$ ), microbial $O M$ for diet $R ;(\Delta)$, microbial OM for diet $C ;(O)$, protozoal OM for diet $R$; (O), protozoal OM for diet $C$.

(Fig. 2(D)). Yet even at the lowest $\mathrm{N}$ level, engulfment of bacterial and protozoal matter resulted in sufficient availability of protein to support protozoal growth. Thus, the slightly lower protozoal $\mathrm{OM}$ at low dietary $\mathbf{N}$ levels could not be attributed to limiting $\mathbf{N}$ availability, but rather was the result of high protozoal death rates induced by high energy availability, which in turn was the result of low bacterial growth rates. These low bacterial growth rates at low dietary $\mathrm{N}$ levels were the result of a high utilization of hexose for nongrowth purposes as shown before (Dijkstra et al. 1992).

In Fig. 3 the responses of microbial and protozoal OM to changes in feed intake level from 5 to $25 \mathrm{~kg} \mathrm{DM} / \mathrm{d}$ are presented. In order to achieve sensible steady-state values, some input values had to be modified (rumen volume, passage rates and $\mathrm{pH}$ ). These values were changed using a linear regression of DM intake $v$. rumen volume, fluid and solid passage rate, calculated from the data reported by Robinson et al. $(1985,1987)$ (feed intake 6.4-18.5 and $5 \cdot 3-21 \mathrm{~kg} \mathrm{DM} / \mathrm{d}$ respectively) and $\mathrm{pH}$ according to the latter (regression results not shown). Increasing the feed intake level to approximately $20 \mathrm{~kg} \mathrm{DM} / \mathrm{d}$ increased both protozoal and total microbial $\mathrm{OM}$, but a further increase caused microbial OM to decrease. On the lowest feed intake level, protozoal contribution to total microbial OM was 10 and $52 \%$ on diets $\mathrm{R}$ and $\mathrm{C}$ respectively. However, increasing the feed intake up to $15 \mathrm{~kg} \mathrm{DM} / \mathrm{d}$ increased this contribution to $16 \%$ on diet $\mathrm{R}$ while on diet $\mathrm{C}$ the contribution was decreased to $35 \%$. Further increases increased protozoal contribution to 17 and $45 \%$ on diets $\mathbf{R}$ and $\mathbf{C}$ respectively. As rumen volume is changed with changes in feed intake level, it is interesting to note the changes in concentration of protozoal OM. On diet $R$ this concentration rapidly increased from $1.80 \mathrm{~g} / 1$ at $5 \mathrm{~kg} \mathrm{DM} / \mathrm{d}$ up to $3.6 \mathrm{~g} / \mathrm{l}$ at $15 \mathrm{~kg} \mathrm{DM} / \mathrm{d}$, and then decreased to $2.7 \mathrm{~g} / 1$ at $25 \mathrm{~kg} \mathrm{DM} / \mathrm{d}$; on diet $\mathrm{C}$ the increase was much less and 
Table 2. Comparisons of experimentally observed* parameters (obs) and parameters predicted by model (pred) for steers fed on diets at low (4.8 $\mathrm{kg}$ dry matter $(D M) / d)$ and high $(7.2 \mathrm{~kg}$ $D M / d$ ) intake levels and at two levels of urea infusion (4 or $12 \mathrm{~g} / \mathrm{kg}$ dietary $D M)$

\begin{tabular}{|c|c|c|c|c|c|c|c|c|}
\hline & \multicolumn{4}{|c|}{ Intake level } & \multicolumn{4}{|c|}{ Urea level } \\
\hline & \multicolumn{2}{|c|}{ Low } & \multicolumn{2}{|c|}{ High } & \multicolumn{2}{|c|}{$0.4 \%$} & \multicolumn{2}{|c|}{$1 \cdot 2 \%$} \\
\hline & Obs & Pred & Obs & Pred & Obs & Pred & Obs & Pred \\
\hline \multicolumn{9}{|l|}{ Duodenal flow of $\mathrm{OM}(\mathrm{g} / \mathrm{d})$} \\
\hline NDF & 1203 & 1235 & 2009 & 2044 & 1591 & 1617 & 1588 & 1589 \\
\hline Total NAN & 107 & 108 & 163 & 165 & 130 & 133 & 140 & 139 \\
\hline Microbial NAN & 62 & 65 & 98 & 96 & 78 & 76 & 83 & 86 \\
\hline Protozoal NAN & - & 8 & - & 11 & - & 10 & - & 9 \\
\hline Non-microbial NAN & 45 & 42 & 64 & 69 & 53 & 56 & 57 & 53 \\
\hline Ammonia concentration (mmol/l) & $4 \cdot 8$ & $4 \cdot 6$ & $5 \cdot 3$ & $4 \cdot 0$ & 3.6 & $2 \cdot 7$ & 6.6 & $6 \cdot 1$ \\
\hline \multicolumn{9}{|l|}{ In rumen $(\mathrm{g})$} \\
\hline Bacterial N & - & 38.0 & - & 48.9 & - & $41 \cdot 7$ & - & 47.4 \\
\hline Protozoal N & - & 15.0 & - & $16 \cdot 3$ & - & $16 \cdot 5$ & - & 15.2 \\
\hline
\end{tabular}

OM, organic matter; NAN, non-ammonia nitrogen; NDF, neutral-detergent fibre.

* Observations are from Firkins et al. (1987).

concentration started to decline at approximately $10 \mathrm{~kg} \mathrm{DM} / \mathrm{d}(5 \cdot 9,6 \cdot 0,5 \cdot 7,5 \cdot 0$ and $4 \cdot 3 \mathrm{~g} / 1$ at $5,10,15,20$ and $25 \mathrm{~kg} \mathrm{DM} / \mathrm{d}$ respectively).

\section{Comparison between simulated and experimental values}

Values of nutrient supply at different intake and feed $\mathbf{N}$ levels reported by Firkins $e t$ al. (1987) for steers fed on hay-concentrate $(50: 50, \mathrm{w} / \mathrm{w})$ diets were used to set a number of microbial parameters in the original model (Dijkstra et al. 1992). The observed values were compared with model simulations (Table 2) to verify that the modified model could reproduce these results. Indeed, there was a close agreement between observed and simulated duodenal flows of OM. However, as in the original model (Dijkstra et al. 1992), $\mathrm{NH}_{3}$ concentration was not predicted well. The microbial marker used by Firkins $e t$ al. (1987) did not allow separate estimates of the protozoal and bacterial $\mathrm{N}$ flow to the duodenum. Model simulations indicated a slight decrease in the proportion of protozoal $\mathrm{N}$ in total microbial $\mathrm{N}$ flow with increased feed intake level (13 and $11 \%$ on low and high intake level respectively) and with increased dietary $\mathrm{N}$ level (13 and $11 \%$ on low and high feed $\mathbf{N}$ level respectively).

Model simulations on protozoal biomass and protozoal turnover and lysis in the rumen compared with observations obtained by isotope dilution procedures in cattle and sheep are presented in Tables 3 and 4 . In the case of sheep simulation the amount of saliva produced was set at a constant level of $121 / \mathrm{d}$. The observed and simulated protozoal turnover is assumed to be due to death and passage of protozoa only, because labelled choline in engulfed protozoa is likely to be incorporated again (Leng, 1982). The simulated protozoal pool sizes in cattle and sheep agreed favourably with observed values, except for the pool size observed on the low-concentrate diet (Ffoulkes \& Leng, 1988). The simulated protozoal contribution to total ruminal microbial $\mathrm{N}$ varied from $12 \%$ on the oat chaff-lucerne chaff diet supplemented with untreated soya-bean meal (Krebs et al. 1989) to $29 \%$ on the oat chaff-molasses (70:30, w/w) diet (Ffoulkes \& Leng, 1988). Both observations and simulations indicated a decreased protozoal biomass when $\mathrm{N}$ availability 
Table 3. Comparison of experimentally observed parameters (obs) and parameters predicted by model (pred) for sheep fed on different diets

\begin{tabular}{|c|c|c|c|c|c|c|c|c|}
\hline & \multicolumn{8}{|c|}{ Diet } \\
\hline & \multicolumn{2}{|c|}{$\mathbf{O}$} & \multicolumn{2}{|c|}{ OC } & \multicolumn{2}{|c|}{ OSU } & \multicolumn{2}{|c|}{ OSP } \\
\hline & Obs & Pred & Obs & Pred & Obs & Pred & Obs & Pred \\
\hline \multicolumn{9}{|l|}{ Rumen pool size of (g) } \\
\hline Protozoal N & $2 \cdot 4$ & $2 \cdot 1$ & $1 \cdot 4$ & 1.6 & 1.5 & $1 \cdot 7$ & 1.6 & 1.8 \\
\hline Microbial N & - & $7 \cdot 3$ & - & $10 \cdot 3$ & - & $14 \cdot 5$ & - & $14 \cdot 1$ \\
\hline Protozoal turnover time (d) & 0.83 & 0.49 & 0.67 & 0.84 & 0.53 & 1.07 & 0.32 & 1.06 \\
\hline Protozoal lysis (\%) & 63 & 80 & 65 & 64 & - & 59 & - & 59 \\
\hline
\end{tabular}

Diet O, oat chaff-lucerne-molasses (Leng, 1982); Diet OC, oat chaff-lucerne-molasses-casein (Leng et al. 1984); Diet OSU, oat chaff-lucerne chaff-untreated soya-bean meal (Krebs et al. 1989); Diet OSP, oat chaff-lucerne chaff-protected soya-bean meal (Krebs et al. 1989).

Table 4. Comparison of experimentally observed parameters (obs) and parameters predicted by model (pred) for cattle fed on different diets

\begin{tabular}{|c|c|c|c|c|c|c|}
\hline & \multicolumn{6}{|c|}{ Diet } \\
\hline & \multicolumn{2}{|c|}{ HC } & \multicolumn{2}{|c|}{ LC } & \multicolumn{2}{|c|}{ RG } \\
\hline & Obs & Pred & Obs & Pred & Obs & Pred \\
\hline $\begin{array}{l}\text { Rumen pool size of (g) } \\
\text { Protozoal N } \\
\text { Microbial N } \\
\text { Protozoal turnover time (d) } \\
\text { Protozoal lysis (\%) }\end{array}$ & $\frac{16}{0.93}$ & $\begin{array}{l}14 \\
55 \\
0 \cdot 69 \\
77\end{array}$ & $\frac{24}{1 \cdot 07}$ & $\begin{array}{l}16 \\
56 \\
0.90 \\
71\end{array}$ & $\frac{15}{1.95}$ & $\begin{array}{l}16 \\
91 \\
1 \cdot 26 \\
54\end{array}$ \\
\hline
\end{tabular}

Diet HC, oat chaff-molasses (30:70, w/w; Ffoulkes \& Leng, 1988); diet LC, oat chaff-molasses $(70: 30$, w/w; Ffoulkes \& Leng, 1988); diet RG, fresh ryegrass (Leng et al. 1986).

was increased (the casein-supplemented oat chaff-lucerne-molasses diet (Leng et al. 1984) compared with the unsupplemented diet (Leng, 1982) and the diet containing untreated soya-bean meal compared with protected soya-bean meal (Krebs et al. 1989)). The turnover time of protozoa in the rumen was not predicted well, without any apparent relationship of level or trend of the difference between observed and predicted values to dietary composition or pattern of protozoal species present. Although predicted contribution of protozoal lysis to protozoal turnover in the rumen did not always agree with observed values, both predicted and observed values indicated the major contribution of lysis (some $55-85 \%$ ) to protozoal turnover.

In Table 5, results of a comparison between model simulations and observations on steers reported by Cockburn \& Williams (1984) are presented. This experiment was chosen because it gave the opportunity to compare several marker methods (RNA as general microbial marker; aminoethylphosphonic acid (AEPA) as protozoal marker; diaminopimelic acid (DAPA) as bacterial marker, and the amino acid (AA) profile of protozoa, bacteria and feed to measure all fractions). The simulated duodenal flow of total nonammonia $\mathrm{N}$ (NAN), which varied from 66 to $111 \%$ of dietary $\mathrm{N}$ intake, was always lower than the observed flow (from 94 to $181 \%$ of dietary $N$ intake). The simulated percentage 
Table 5. Comparison of experimentally observed* parameters (obs) and parameters predicted by a mathematical rumen model (pred) for steers fed on straw/tapioca-based diets

\begin{tabular}{|c|c|c|c|c|c|c|c|c|}
\hline & \multicolumn{8}{|c|}{ Diet } \\
\hline & \multicolumn{2}{|c|}{$\mathbf{U}$} & \multicolumn{2}{|c|}{$\mathbf{G M}$} & \multicolumn{2}{|c|}{ C } & \multicolumn{2}{|c|}{ TC } \\
\hline & Obs & Pred & Obs & Pred & Obs & Pred & Obs & Pred \\
\hline Duodenal flow of NAN $(\mathrm{g} / \mathrm{d})$ & $33-4$ & $23 \cdot 3$ & 47.0 & 34.9 & 43.8 & $37 \cdot 4$ & 67.8 & $41 \cdot 7$ \\
\hline \multicolumn{9}{|l|}{$\begin{array}{l}\text { Rumen outflow of } \\
\text { (\% total NAN flow): }\end{array}$} \\
\hline Microbial NAN, RNA $\dagger$ & 98 & & 85 & & 92 & & 53 & \\
\hline Microbial NAN, AEPA + DAPA & 144 & 87 & 102 & 71 & 108 & 72 & 73 & 54 \\
\hline Microbial NAN, mAA & 89 & & 75 & & 84 & & 54 & \\
\hline Protozoal NAN, RNA-DAPA & 10 & & 15 & & 11 & & -4 & \\
\hline Protozoal NAN, AEPA & 56 & 11 & 32 & 6 & 27 & 6 & 16 & 6 \\
\hline Protozoal NAN, mAA & 25 & & 14 & & 9 & & 25 & \\
\hline Bacterial NAN, DAPA & 88 & 76 & 70 & 65 & 81 & 66 & 57 & 48 \\
\hline \multicolumn{9}{|l|}{ Rumen pool size of $(\mathrm{g})$} \\
\hline Protozoal N & - & 6.7 & - & $5 \cdot 5$ & - & 5.6 & - & $6 \cdot 0$ \\
\hline Microbial N & - & $20-5$ & - & $25 \cdot 8$ & - & $24 \cdot 3$ & - & $20 \cdot 6$ \\
\hline
\end{tabular}

Diet U, urea supplementation; diet GM, groundnut meal supplementation; diet C, untreated casein supplementation; diet TC, formaldehyde-treated casein supplementation; NAN, non-ammonia nitrogen.

* Observations are from Cockburn \& Williams (1984).

† Microbial markers used: RNA, ribonucleic acid; AEPA, aminoethylphosphonic acid; DAPA, diaminopimelic acid,; mAA, modified amino acid profile.

of microbial NAN to total NAN flow agreed with the value obtained by the modified AA (mAA) method, but was always lower than values obtained by the RNA or DAPA + AEPA methods. As indicated previously, the simulated protozoal contribution to total microbial $\mathbf{N}$ in the rumen increased with decreases in $\mathbf{N}$ availability, but due to the increased nonmicrobial NAN flow (formaldehyde-treated casein compared with untreated casein and groundnut meal supplementation) the percentage of protozoal NAN to total NAN flow was not increased. The AEPA + DAPA method clearly overestimated microbial NAN flow, and both simulated protozoal and bacterial NAN percentage flows were lower than values obtained with AEPA and DAPA. Simulated protozoal NAN (which varied between 6 and $11 \%$ of total NAN flow) was in the range obtained with the RNA-DAPA method (between -4 and $15 \%$ ) but lower than the mAA method (between 9 and $25 \%$ ). An important point in these comparisons is that disagreements between simulated and observed values partly result from inadequacies of input data describing the diets or errors in experimental measurements.

\section{DISCUSSION}

The basic objective of the model was to achieve an integrated understanding of the relative roles of protozoa and bacteria in degradation of substrates and supply of nutrients available for absorption, as determined by dietary characteristics. Mathematical, mechanistic models provide a way to accomplish this integration (Thornley \& Johnson, 1990). Several types of equation have been applied to describe mathematically the interrelationships among microbial species in multi-species systems. The Lotka-Volterra equations have been used extensively (e.g. Brown \& Rothery, 1993). However, the application of these equations to predator-prey (here: protozoa-bacteria) systems has been 
questioned, because of the biologically unrealistic results (Bazin, 1981) and the structural instability of the model (Brown \& Rothery, 1993). Reichl \& Baldwin (1976) described a linear programming model of rumen fermentation in which eight microbial groups, including protozoa, were represented. Considerable simplifications of the predicted rumen ecosystem occurred and the authors concluded that additional concepts regarding microbial interactions were required. In microbiology, Monod functions are often used to represent behaviour of species in multi-species systems (Pirt, 1975). These microbial growth functions are identical to the Michaelis-Menten equations (Gill et al. 1989). Bacterial engulfment by protozoa has been represented by Michaelis-Menten forms as well, assuming that at a low bacterial concentration in rumen fluid, protozoa would search thoroughly in order to secure ample uptake of bacteria, whereas at a high bacterial concentration, protozoa would reduce their search efforts because of satiation. In order to represent such behaviour, Holling (1959) proposed a model in which the predation rate follows a rectangular hyperbola identical to the Michaelis-Menten equation. Holling's (1959) equation has been found to provide a good fit to experimental data on a wide range of predator species (Brown \& Rothery, 1993). Application of these equations allowed representation of protozoal predation on bacteria in the rumen (Dijkstra et al. 1992). However, important simplifications had to be made, the most obvious one being the representation of a microbial group consisting of both amylolytic bacteria and protozoa. This resulted in incorrect predictions of fibre degradation when starch content of the diet increased or when a defaunated animal was simulated (Neal et al. 1992). In the modified model, emphasis has been placed on the representation of protozoa and cellulolytic and amylolytic bacteria in separate groups. Important items in analyses of such multi-species systems are the factors which allow populations to coexist and stability of coexistence (De Freitas \& Fredrickson, 1978; Brown \& Rothery, 1993). A general condition for stable coexistence is that the number of nutrients having rate-limiting effects on the competitors equals or exceeds the number of populations in the system (De Freitas \& Fredrickson, 1978). For the present model, in most dietary situations energy substrates would limit growth, while $\mathbf{N}$ substrates would affect microbial growth at relatively low $\mathrm{N}$ availability only. Hence, in early versions of the model, which did not include protozoal predation on other protozoa and in which death rate was fixed, the two substrates limiting growth (amylolytic and cellulolytic hexose) led to exclusion of either cellulolytic and amylolytic bacteria or of protozoa. To obtain biologically realistic coexistence of the populations, in the present model the protozoal death rate was related to substrate availability and buildup of fermentation endproducts within protozoa (Prins \& Van Hoven, 1977; Williams, 1979). The uptake of protozoa by other protozoa (reviewed by Coleman, 1986) was included as well. Analogously to the stabilizing effect of production of specific autoinhibitors on coexistence of populations (De Freitas \& Fredrickson, 1978), this representation of protozoal metabolism and interactions with bacteria allowed stable coexistence under a wide range of dietary inputs. It should be noted that there are at least two situations where simulated coexistence does not occur. First, at high intake levels of concentrate diets the high availability of easily fermentable substrates resulted in high protozoal death rates and in low $\mathrm{pH}$ values of rumen fluid, and high fractional outflow rates are presumed. Hence, both protozoa and cellulolytic bacteria disappeared. The results reported by Eadie et al. (1970) and Russell \& Dombrowski (1980) support such a disappearance of protozoa and cellulolytic bacteria respectively. Second, on diets without soluble sugars and all starch available in the insoluble form, amylolytic bacteria would be excluded (results not shown). However, such diets are unlikely to be fed (Tamminga et al. 1990). 
Sensitivity analysis

A full discussion of the results of sensitivity analysis is given elsewhere (Dijkstra, 1993, chapter 4). The model was very sensitive to variations in the maintenance requirement of protozoa. Such variations gave rise to simulated disappearance of either bacteria or protozoa (Dijkstra, 1993, chapter 4). To the author's knowledge, there are no published data on protozoal maintenance requirements in the literature. This value has been set at a value slightly higher than the maintenance requirement estimated for mixed bacteria in vitro reported by Isaacson et al. (1975) and is within the range of endogenous amylopectin utilization by holotrich protozoa reported by Prins \& Van Hoven (1977) and Van Hoven \& Prins (1977). The affinity constant related to death of protozoa significantly influenced microbial populations as well. In the model, death rate is assumed to be related to rate of fermentation of hexoses within protozoa, to represent the observed lysis of protozoa at high availability of easily fermentable substrates (Prins \& Van Hoven, 1977; Williams, 1979). Such a representation ignores other reasons for protozoal lysis, including presence of lytic agents and of toxic chemicals, and the effects of oxygen intake in feed (Leng, 1989). However, the behaviour of the model at the diets used in sensitivity analysis is satisfactory (Dijkstra, 1993, chapter 4). When the availability of easily degradable carbohydrates is raised to a high level, in vivo amylolytic bacterial numbers increase and protozoal numbers decrease (Mackie et al. 1978), and model simulations agreed qualitatively with such changes in the rumen microbial population. The sensitivity analyses highlighted the need for further research to obtain quantitative data on bacterial engulfment rate, protozoal maintenance requirement and death rate as affected by the diet (Dijkstra, 1993, chapter 4). Besides, the absence of adequate data to estimate these parameter values will limit the potential increase in quantitative understanding of the protozoal dynamics.

\section{Responses to changes in input parameters}

The model provides the opportunity to change dietary components independently and study the effects on microbial populations in the rumen. In line with results reported in the review of Jouany (1989), simulated protozoal biomass was greatly influenced by variations in dietary starch, but was less affected by variations in dietary contents of sugars and did not change in response to variations in dietary NDF contents (Fig. 2). However, responses to increases in dietary starch contents depended on the type of diet and the level of starch content. Increasing the starch content from 300 to $400 \mathrm{~g} / \mathrm{kg} \mathrm{DM}$ decreased protozoal biomass on diet $\mathrm{C}$ but increased protozoal biomass on diet $\mathrm{R}$. The reason for the decreased protozoal biomass on diet $\mathbf{C}$ is a much higher increase in simulated protozoal death rate. Thus, the model provides a mechanism for examining the relationship between protozoal $\mathrm{OM}$ in the rumen and dietary composition, taking into account the dynamic behaviour of microbial populations in the rumen. Equally, supplementation of roughage diets with small amounts of soluble sugars increased protozoal biomass, while on concentrate diets protozoal biomass was decreased due to protozoal lysis. Simulations indicate that this difference between diets would have been even more pronounced had the roughage diets contained no starch (results not shown). While bacterial biomass was increased with an improved ruminal $\mathbf{N}$ availability, protozoal biomass was hardly changed. This is the result of the assumption made in the model that, in most situations, and even when dietary protein content is low, protozoa do not lack $\mathbf{N}$ since sufficient protein is available from engulfed microbial matter. These simulations show the importance of including dynamic interactions between protozoa, bacteria and dietary characteristics in order to examine the effects of changes in dietary composition on microbiological parameters and degradation of $\mathrm{OM}$ in the rumen. 
In simulations, changes in feed intake level had to be accompanied by changes in passage rates, rumen volume and $\mathrm{pH}$ of rumen fluid as have been reported in the literature (Robinson et al. 1985, 1987; Owens \& Goetsch, 1986). Ad lib. intake of high-concentrate diets led to low protozoal numbers in rumen fluid or even complete disappearance (Eadie et al. 1970; Slyter et al. 1970; Vance et al. 1972), but doubling the feed intake of a hay-based diet increased protozoal numbers (Jouany, 1989). Thus, model simulations which indicate that the effect of feed intake level on changes of the concentration of protozoal biomass in the rumen depended on dietary composition and basal feed intake level are qualitatively in line with observations. The simulated death rates of protozoa were increased to a much larger extent by increases in feed intake with diet $\mathbf{C}$ than with $\operatorname{diet} \mathbf{R}$. With diet $\mathbf{C}$, maximal protozoal concentrations are reached at a lower level of intake. Thus, the model provides a mechanistic understanding of the changes in protozoal concentration resulting from changes in feed intake level and provide a quantitative description of such changes.

It should be noted that with increased intake levels the proportion of amylolytic bacterial $\mathrm{N}$ to total bacterial $\mathrm{N}$ is increased. Because of higher fractional outflow of amylolytic than cellulolytic bacteria, these changes imply that variations in the protozoal contribution to rumen microbial biomass are not necessarily accompanied by changes of the same relative size in protozoal contribution to microbial NAN flow. For example, on diet $\mathrm{C}$ the contribution of protozoal $\mathrm{N}$ to rumen microbial $\mathrm{N}$ on the lowest and highest intake level differed only slightly (47 and $46 \%$ respectively), yet protozoal contribution to microbial NAN outflow varied more (18 and $12 \%$ respectively). Thus, estimations of proportional contributions of protozoa to microbial NAN flow vary with different levels of intake of a diet and cannot be based on protozoal biomass in the rumen alone. Specific nutritional aspects of protozoa, including dissimilarities in amino acid profile of protozoal and bacterial protein (Buttery, 1977), selective retention within the rumen (reviewed by Jouany et al. 1988), and the general absence of propionic acid in protozoal fermentation endproducts (reviewed by Williams \& Coleman, 1988), will cause differences in the profile of nutrients available for absorption. It is hoped that results of the model, giving a quantification of protozoal contribution to rumen microbial metabolic activities related to dietary characteristics, will encourage research into integrating protozoal activities with the profile of nutrients available for absorption.

\section{Comparison between simulated and experimental values}

The comparison between simulated and experimental values on protozoa and protozoal dynamics presented a major problem. Several methods have been proposed to estimate protozoal biomass in the rumen and protozoal outflow to the duodenum and results differ widely. The number of protozoa in rumen fluid is an unreliable indicator of protozoal biomass in the rumen (Leng, 1989), because of large diurnal and between-animal variation (Coleman, 1986) and because of a close association of rumen entodiniomorphid protozoa to plant fragments (Bauchop \& Clarke, 1976; Amos \& Akin, 1978) and of holotrich protozoa to the reticulo-rumen wall (Abe et al. 1981). Estimation of protozoal outflow to the duodenum by use of a specific protozoal marker (AEPA, Ling \& Buttery, 1978; Whitelaw et al. 1984) or from the difference between microbial NAN flow measured with a general microbial marker (e.g. ${ }^{15} \mathrm{~N},{ }^{35} \mathrm{~S}, \mathrm{RNA}$ ) and a bacterial marker (DAPA) yielded highly variable and biased results (Oldham \& Tamminga, 1980; Cockburn \& Williams, 1984; Ling, 1990). Isotope dilution techniques using $\left[{ }^{14} \mathrm{C}\right]$ choline have been applied to measure protozoal dynamics in the rumen and their application has been discussed elsewhere (Czerkawski, 1987; Leng, 1989). On most diets, protozoal biomass in the rumen was adequately predicted when compared with values obtained by the $\left[{ }^{14} \mathrm{C}\right]$ choline method (Tables 3 and 4). Unfortunately, all but one of the diets were based on oat chaff and this 
limits the scope of comparison. Thus, further evaluation requires reliable estimates of protozoal biomass on a range of dietary conditions.

Simulated protozoal turnover time was not predicted well without any consistent pattern of over- or underestimation. Estimates of protozoal biomass and turnover time obtained with the $\left[{ }^{14} \mathrm{C}\right]$ choline method are not independent, however. It was striking that, on most diets, an overestimated rumen protozoal pool size was accompanied by an overestimated turnover time, and vice versa. Hence, the differences between simulated and observed protozoal production rates in the rumen (calculated as the reciprocal of turnover time multiplied by protozoal biomass and expressed in g protozoal $\mathrm{N} / \mathrm{d}$ ) were smaller than the differences between observed and simulated turnover times. Simulated turnover times were calculated ignoring the turnover due to uptake of protozoa by other protozoa. Thus, 'true' turnover time would be lower than values stated in Tables 3 and 4. Both experimental $(63-83 \%)$ and simulated (54-80\%) values of protozoal lysis indicate the major contribution of lysis to protozoal turnover. Czerkawski (1987) questioned this contribution and described a model in which protozoa in the liquid phase of rumen digesta were assumed to leave the rumen with the same rate as the fractional fluid passage rate, whereas protozoa in the solid phase of digesta would not leave the rumen at all. He argued that a much larger part of protozoal biomass than estimated with the $\left[{ }^{14} \mathrm{C}\right]$ choline method flows out the rumen but is lysed in the omasum. However, evidence reported by Michalowski \& Harmeyer (1983), Coleman (1988) and Leng (1989) does not support the suggested lysis of protozoa in the omasum. The simulated proportion of protozoal NAN in microbial NAN outflow on the range of diets in Tables 2-5 was low (6-13\%). Using direct counts, Weller \& Pilgrim (1974) calculated that protozoal $\mathrm{N}$ outflow amounted to $1-2 \%$ of dietary $\mathrm{N}$ intake only and, with the same method, Collombier et al. (1984) and Punia et al. (1987) calculated a contribution of 5 and $24-27 \%$ of protozoal to total microbial NAN flow respectively. Steinhour et al. (1982), using a ${ }^{15} \mathrm{~N}$ rate of incorporation method, calculated $33-51 \%$ of microbial NAN flow to be of protozoal origin. John \& Ulyatt (1984) obtained much lower values (9-19\%) using phosphatidyl choline to estimate protozoal flow. As discussed before, the method using the difference between a general microbial and a bacterial marker yields a wide range of estimates of protozoal NAN flows. Thus, most methods indicate a relatively low protozoal outflow, but for further evaluation there is a real need for a valid protozoal marker.

In conclusion, the model provides a mathematical representation of the substrates and microbial populations in the rumen with special emphasis on protozoa. It gives an improved understanding of the protozoal dynamics and interactions with rumen bacteria as affected by dietary characteristics. Both very low and high availability of energy substrates resulted, by different mechanisms, in low protozoal levels in the rumen. The responses to changes in dietary composition and feed intake level have been given and differences in response to one particular aspect of dietary input have been discussed with respect to basal level of the other dietary inputs. The need for reliable estimates of protozoal biomass, turnover and outflow on a range of diets has been indicated, as well as the lack of quantitative data on bacterial engulfment and protozoal maintenance requirement and death rate.

\section{REFERENCES}

Abe, M., Iriki, T., Tobe, N. \& Shibui, H. (1981). Sequestration of holotrich protozoa in the reticulo-rumen of cattle. Applied and Environmental Microbiology 41, 758-765.

Amos, H. E. \& Akin, D. E. (1978). Rumen protozoal degradation of structurally intact forage tissues. Applied and Environmental Microbiology 36, 513-522.

Bauchop, T. \& Clarke, R. T. J. (1976). Attachment of the ciliate Epidinium Crawley to plant fragments in the sheep rumen. Applied and Environmental Microbiology 32, 417-422. 
Bazin, M. J. (1981). Mixed culture kinetics. In Mixed Culture Fermentations, pp. 25-51 [M. E. Bushell and J. H. Slater, editors]. London: Academic Press.

Brown, D. \& Rothery, P. (1993). Models in Biology: Mathematics, Statistics and Computing. Chichester: John Wiley \& Sons Ltd.

Buttery, P. J. (1977). Aspects of the biochemistry of rumen fermentation and their implication in ruminant productivity. In Recent Advances in Animal Nutrition 1977, pp. 8-24 [W. Haresign and D. Lewis, editors]. London: Butterworths.

Cockburn, J. E. \& Williams, A. P. (1984). The simultaneous estimation of the amounts of protozoal, bacterial and dietary N entering the duodenum of steers. British Journal of Nutrition 51, 111-132.

Coleman, G.S. (1967). The metabolism of free amino acids by washed suspensions of the rumen ciliate Entodinium caudatum. Journal of General Microbiology 47, 433-447.

Coleman, G. S. (1975). The interrelationship between rumen ciliate protozoa and bacteria. In Digestion and Metabolism in the Ruminant, pp. 149-164 [I. W. McDonald and A. C. I. Warner, editors]. Armidale: University of New England Publishing Unit.

Coleman, G. S. (1986). The metabolism of rumen ciliate protozoa. FEMS Microbiological Reviews 39, 321-344.

Coleman, G.S. (1988). The importance of rumen ciliate protozoa in the growth and metabolism of the host ruminant. International Journal of Animal Science 3, 75-95.

Coleman, G. S. (1989). Protozoal-bacterial interactions in the rumen. In The Roles of Protozoa and Fungi in Ruminant Digestion, pp. 13-27 [J. V. Nolan, R. A. Leng and D. I. Demeyer, editors]. Armidale: Penambul Books.

Collombier, J., Grolière, C. A., Senaud, J., Grain, J. \& Thivend, P. (1984). Etude du rôle des protozoaires ciliés du rumen dans l'apport d'azote microbien entrant dans le duodénum du ruminant, par l'estimation directe de la quantité de ciliés sortant du rumen (Study on the role of rumen ciliate protozoa in the production and passage of microbial nitrogen to the duodenum of ruminants by direct estimation of the number of ciliates leaving the rumen). Protistologica 20, 431-436.

Czerkawski, J. W. (1976). Chemical composition of microbial matter in the rumen. Journal of the Science of Food and Agriculture 27, 621-632.

Czerkawski, J. W. (1987). Reassessment of the contribution of protozoa to the microbial protein supply to the host ruminant animal. Journal of Theoretical Biology 126, 335-341.

De Freitas, M. J. \& Fredrickson, A. G. (1978). Inhibition as a factor in the maintenance of the diversity of microbial ecosystems. Journal of General Microbiology 106, 307-320.

Demeyer, D. I., Henderson, C. R. \& Prins, R. A. (1978). Relative significance of exogenous and de novo synthesized fatty acids in the formation of rumen microbial lipids in vitro. Applied and Environmental Microbiology 35, 24-31.

Dijkstra, J. (1993). Mathematical modelling and integration of rumen fermentation processes. $\mathrm{PhD}$ Thesis, Wageningen: Agricultural University.

Dijkstra, J., Neal, H. D. St C., Beever, D. E. \& France, J. (1992). Simulation of nutrient digestion, absorption and outflow in the rumen: model description. Journal of Nutrition 122, 2239-2256.

Dijkstra, J., Neal, H.D. St C., Gill, M., Beever, D. E. \& France, J. (1990). Representation of microbial metabolism in a mathematical model of rumen fermentation. In Proceedings of the Third International Workshop on Modelling Digestion and Metabolism in Farm Animals, pp. 47-63 [A. B. Robson and D. P. Poppi, editors]. Lincoln: Lincoln University Press.

Eadie, J. M., Hyldgaard-Jensen, J., Mann, S. O., Reid, R. S. \& Whitelaw, F. G. (1970). Observations on the microbiology and biochemistry of the rumen in cattle given different quantities of a pelleted barley ration. British Journal of Nutrition 24, 157-177.

Faichney, G. J. (1989). Mean retention time and intra-ruminal degradation of rumen protozoa. Proceedings of the Nutrition Society of Australia 14, 135.

Ffoulkes, D. \& Leng, R. A. (1988). Dynamics of protozoa in the rumen of cattle. British Journal of Nutrition 59, $429-436$.

Firkins, J. L., Lewis, S. M., Montgomery, L., Berger, L. L., Merchen, N. R. \& Fahey, G. C. Jr (1987). Effects of feed intake and dietary urea concentration on ruminal dilution rate and efficiency of bacterial growth in steers. Journal of Dairy Science 70, 2312-2321.

Forsberg, C. W., Lovelock, L. K. A., Krumholz, L. \& Buchanan-Smith, J. G. (1984). Protease activities of rumen protozoa. Applied and Environmental Microbiology 47, 101-110.

Gill, M., Beever, D. E. \& France, J. (1989). Biochemical bases needed for the mathematical representation of whole animal metabolism. Nutrition Research Reviews 2, 181-200.

Hino, T. \& Russell, J. B. (1985). Effect of reducing equivalent disposal and NADH-NAD on deamination of amino acids by intact rumen microorganisms and their cell extracts. Applied and Environmental Microbiology 50, 1368-1374.

Hino, T. \& Russell, J. B. (1987). Relative contributions of ruminal bacteria and protozoa to the degradation of protein in vitro. Journal of Animal Science 64, 261-270.

Holling, C. S. (1959). Some characteristics of simple types of predation and parasitism. Canadian Entomologist 91 , 385-398.

Hungate, R. E. (1966). The Rumen and its Microbes. New York: Academic Press. 
Isaacson, H. R., Hinds, F. C., Bryant, M. P. \& Owens, F. N. (1975). Efficiency of energy utilization by mixed rumen bacteria in continuous culture. Journal of Dairy Science 58, 1645-1659.

John, A. \& Ulyatt, M. J. (1984). Measurement of protozoa, using phosphatidyl choline, and of bacteria, using nucleic acids, in the duodenal digesta of sheep fed chaffed lucerne hay (Medicago sativa L.) diets. Journal of Agricultural Science, Cambridge 102, 33-44.

Jouany, J. P. (1989). Effects of diet on populations of rumen protozoa in relation to fibre digestion. In The Roles of Protozoa and Fungi in Ruminant Digestion, pp. 59-74 [J. V. Nolan, R. A. Leng and D. I. Demeyer, editors]. Armidale: Penambul Books.

Jouany, J. P., Demeyer, D. I. \& Grain, J. (1988). Effect of defaunating the rumen. Animal Feed Science and Technology 21, 229-265.

Krebs, G. A., Leng, R. A. \& Nolan, J. V. (1989). Microbial biomass and production rates in the rumen of faunated and fauna-free sheep on low protein fibrous feeds with or without nitrogen supplementation. In The Roles of Protozoa and Fungi in Ruminant Digestion, pp. 295-299 [J. V. Nolan, R. A. Leng and D. I. Demeyer, editors]. Armidale: Penambul Books.

Leng, R. A. (1982). Dynamics of protozoa in the rumen of sheep. British Journal of Nutrition 48, 399-415.

Leng, R. A. (1989). Dynamics of protozoa in the rumen. In The Roles of Protozoa and Fungi in Ruminant Digestion, pp. 51-58 [J. V. Nolan, R. A. Leng and D. I. Demeyer, editors]. Armidale: Penambul Books.

Leng, R. A., Dellow, D. \& Waghorn, G. (1986). Dynamics of large ciliate protozoa in the rumen of cattle fed on diets of freshly cut grass. British Journal of Nutrition 56, 455-462.

Leng, R. A., Nolan, J. V., Cumming, G., Edwards, S. R. \& Graham, C. A. (1984). The effects of monensin on the pool size and turnover rate of protozoa in the rumen of sheep. Journal of Agricultural Science, Cambridge 102 , $609-613$.

Ling, J. R. (1990). Digestion of bacterial cell walls in the rumen. In The Rumen Ecosystem. The Microbial Metabolism and its Regulation, pp. 83-90 [S. Hoshino, R. Onodera, H. Minato and H. Itabashi, editors]. Tokyo: Japan Scientific Societies Press.

Ling, J. R. \& Buttery, P. J. (1978). The simultaneous use of ribonucleic acid, ${ }^{35} \mathrm{~S}, 2,6$-diaminopimelic acid and 2aminoethylphosphonic acid as markers of microbial nitrogen entering duodenum of sheep. British Journal of Nutrition 39, 165-179.

Mackie, R. I., Gilchrist, F. M. C., Robberts, A. M., Hannah, P. E. \& Schwartz, H. M. (1978). Microbiological and chemical changes in the rumen during the stepwise adaptation of sheep to high concentrate diets. Journal of Agricultural Science, Cambridge 90, 241-254.

Michalowski, T. \& Harmeyer, J. (1983). Selective outflow of protozoa frorn the rumen of sheep. In Protein Metabolism and Nutrition, vol. 2, pp. 292-294 [R. Pion, M. Arnal and D. Bonin, editors]. Paris: INRA.

Mitchell, E. L. \& Gauthier, J. (1981). Advanced Continuous Simulation Language. User Guide/Reference Manual, 3rd ed. Concord: Mitchell and Gauthier Ass.

Murphy, M. R., Baldwin, R. L. \& Koong, L. J. (1982). Estimation of stoichiometric parameters for rumen fermentation of roughage and concentrate diets. Journal of Animal Science 55, 411-421.

Neal, H. D. St C., Dijkstra, J. \& Gill, M. (1992). Simulation of nutrient digestion, absorption and outflow in the rumen: model evaluation. Journal of Nutrition 122, 2257-2272.

Nolan, J. V. (1989). Implications of protozoa and fungi for the protein nutrition of ruminants. In The Roles of Protozoa and Fungi in Ruminant Digestion, pp. 211-221 [J. V. Nolan, R. A. Leng and D. I. Demeyer, editors] Armidale: Penambul Books.

Oldham, J. D. \& Tamminga, S. (1980). Amino acid utilization by dairy cows. 1. Methods of varying amino acid supply. Livestock Production Science 7, 437-452.

Owens, F. N. \& Goetsch, A. L. (1986). Digesta passage and microbial protein synthesis. In Control of Digestion and Metabolism in Ruminants, pp. 196-223 [L. P. Milligan, W. L. Grovum and A. Dobson, editors]. Englewood Cliffs: Prentice-Hall.

Pirt, S. J. (1965). The maintenance energy of bacteria in growing cultures. Proceedings of the Royal Society London, Series B 163, 224-231.

Pirt, S. J. (1975). Principles of Microbe and Cell Cultivation. Oxford: Blackwell Scientific Publications.

Prins, R. A. \& Van Hoven, W. (1977). Carbohydrate fermentation by the rumen ciliate Isotricha prostoma. Protistologica 13, 549-556.

Punia, B. S., Leibholz, J. \& Faichney, G. J. (1987). The role of rumen protozoa in the utilization of paspalum (Paspalum dilatatum) hay by cattle. British Journal of Nutrition 57, 395-406.

Reichl, J. R. \& Baldwin, R. L. (1976). A rumen linear programming model for evaluation of concepts of rumen microbial function. Journal of Dairy Science 59, 439-454.

Robinson, P. H., Sniffen, C. J. \& Van Soest, P. J. (1985). Influence of level of feed intake on digestion and bacterial yield in the forestomachs of dairy cattle. Canadian Journal of Animal Science 65, 437-444.

Robinson, P. H., Tamminga, S. \& Van Vuuren, A. M. (1987). Influence of declining level of feed intake and varying the proportion of starch in the concentrate on rumen ingesta quantity, composition and kinetics of ingesta turnover in dairy cows. Livestock Production Science 17, 37-62.

Russell, J. B. \& Dombrowski, D. B. (1980). Effect of $\mathrm{pH}$ on the efficiency of growth by pure cultures of rumen bacteria in continuous culture. Applied and Environmental Microbiology 39, 604-610.

Slyter, L. L., Otjen, R. R., Kern, D. L. \& Blank, F. C. (1970). Influence of type and level of grain and 
diethylstilbestrol on the rumen microbial population of steers fed all-concentrate diets. Journal of Animal Science 31, 996-1002.

Stein, W. D. (1986). Transport and Diffusion Across Cell Membranes. Orlando: Academic Press.

Steinhour, W. D., Stokes, M. R., Clark, J. H., Rogers, J. A. \& Davis, C. L. (1982). Estimation of the proportion of non-ammonia-nitrogen reaching the lower gut of the ruminant derived from bacterial and protozoal nitrogen. British Journal of Nutrition 48, 417-431.

Tamminga, S., Van Vuuren, A. M., Van der Koelen, C. J., Ketelaar, R. S. \& Van der Togt, P. L. (1990). Ruminal behaviour of structural carbohydrates, non-structural carbohydrates and crude protein from concentrate ingredients in dairy cows. Netherlands Journal of Agricultural Science 38, 513-526.

Thornley, J. H. M. \& Johnson, I. R. (1990). Plant and Crop Modelling. A Mathematical Approach to Plant and Crop Physiology. Oxford: Clarendon Press.

Vance, R. D., Preston, R. L., Klosterman, E. W. \& Cahill, V. R. (1972). Utilization of whole shelled and crimped corn grain with varying proportions of corn silage by growing-finishing steers. Journal of Animal Science 35 , 598-605.

Van Hoven, W. \& Prins, R. A. (1977). Carbohydrate fermentation by the rumen ciliate Dasytricha ruminantium. Protistologica 13, 599-606.

Veira, D. M. (1986). The role of ciliate protozoa in nutrition of the ruminant. Journal of Animal Science 63, $1547-1560$.

Wallace, R. J. \& Cotta, M. A. (1988). Metabolism of nitrogen-containing compounds. In The Rumen Microbial Ecosystem, pp. 217-249 [P. N. Hobson, editor]. London: Elsevier Science Publishers.

Weller, R. A. \& Pilgrim, A. F. (1974). Passage of protozoa and volatile fatty acids from the rumen of the sheep and from a continuous in vitro fermentation system. British Journal of Nutrition 32, 341-351.

Whitelaw, F. G., Eadie, J. M., Bruce, L. A. \& Shand, W. J. (1984). Microbial protein synthesis in cattle given roughage-concentrate and all-concentrate diets: the use of 2,6-diaminopimelic acid, 2-aminoethylphosphonic acid and ${ }^{35} \mathrm{~S}$ as markers. British Journal of Nutrition 52, $249-260$.

Williams, A. G. (1979). The selectivity of carbohydrate assimilation by the anacrobic rumen ciliate Dasytricha ruminantium. Journal of Applied Bacteriology 47, 511-520.

Williams, A. G. (1986). Rumen holotrich protozoa. Microbiological Reviews 50, 25-49.

Williams, A. G. (1989). Metabolic activities of rumen protozoa. In The Roles of Protozoa and Fungi in Ruminant Digestion, pp. 97-126 [J. V. Nolan, R. A. Leng and D. I. Demeyer, editors]. Armidale: Penambul Books.

Williams, A. G. \& Coleman, G. S. (1988). The rumen protozoa. In The Rumen Microbial Ecosystem, pp. 77-128 [P. N. Hobson, editor]. London: Elsevier Science Publishers. 